\title{
Blood Line
}

\section{Priscila Uppal}

De plus en plus, les exploits de la science se présentent comme des mythes. Notre sang pourrait être créé, détruit, conservé, contaminé, infecté, transformé, copié, tranfusé et utilisé pour nous ou contre nous. À la manière d'un mythe, tout ce que nous lisons sur de telles expérimentations est raconté comme si le corps n'existait pas et que la violence pouvait être exercée sans conséquence. Mon poème "Blood line » veut explorer les tensions entre le sang tel qu'il est utilisé dans l'imagerie d'Épinal de nos vies et le sang réel qui coule dans nos veines.

Because "blood" is an idea, someone always wants to tamper with it. Forgetting it the center of all horror stories.

The ultimate excuse for all sorts of bad behavior.

If one could measure the word with the actual substance, our family trees would be soaked.

Doctor's pamphlets contagious.

Television screens unwatchable.

Our myths would stink

like the hottest trash.

As eventually:

the line is cut: be it silently

or violently.

Be it by the scientists with their silver test tubes

and end results. 
Be it by the scientists with their silver test tubes

and end results.

Be it by cutting off a woman's tongue so she cannot utter her father's name. 